\title{
LONGITUDINAL ECOLOGICAL ZONATION IN FOUR ALGERIAN STREAMS
}

\author{
Djamel Eddine Zouakh ${ }^{1,2}$ and Abderrafik Meddour ${ }^{2}$ \\ ${ }^{1}$ ESSAIA, Avenue Ahmed Hamidouche, Beaulieu, El Harrach 16200, Algeria. \\ ${ }^{2}$ Aquaculture \& Pathology Research Laboratory, Annaba University, 23000, \\ Algeria. \\ dzouakh@gmail.com
}

\begin{abstract}
Djamel Eddine Zouakh and Abderrafik Meddour, 2018. Longitudinal ecological zonation in four Algerian streams. Lebanese Science Journal, 19(2): 135-149.
\end{abstract}

This hydro-biological survey on benthic invertebrates was carried out in the most important hydrographic network of the Mitidja plain, Oued El Harrach basin, Algeria. Results revealed ecological zonation taking into account the taxonomic richness and the relative abundance of different zoological groups, and allowed distinguishing abundant, ubiquitous and permanent taxa as well as the existence of a spatiotemporal faunistic gradient. These preliminary results allowed highlighting taxonomically the "upstream invertebrate fauna", the "ubiquitous invertebrate fauna" and the "downstream invertebrate fauna". Consequently, it appeared that Plecoptera, Hemiptera, Coleoptera are characteristic to the upstream area during the whole year in most of the sampling sites, whereas Diptera, Oligochaeta and Hydracarina are more abundant in the downstream area but in less density in the middle stream. On the other hand, the longitudinal evolution approach was considered in order to evaluate the inter-site distribution. According to the trophic levels, the classification between the various communities was investigated taking into account the concepts of the "Food Functional Group" and "The River Continuum Concept".

Keywords: ecological zonation, trophic relations, invertebrates, freshwater. 


\section{$R \dot{E} S U M E ́$}

\section{Djamel Eddine Zouakh et Abderrafik Meddour, 2018. Zonation écologique longitudinale dans quatre cours d'eau algériens. Journal Scientifique Libanaise, 19(2): 135-149.}

Cette étude qualitative et quantitative des macroinvertébrés benthiques a été réalisée dans le plus important bassin de la Mitidja dans la région d'Alger; l'oued El Harrach et ses principaux affluents. Les résultats mettent en relief une zonation écologique tenant compte de la richesse taxonomique et de l'abondance relative des différents groupes zoologiques; ils ont permis de distinguer "la faune des stations en amont", la "faune ubiquiste" et la "faune des stations en aval". Conséquemment, les Plécoptères, Hémiptères et Coléoptères caractérisent le cours supérieur pendant toute l'année dans la plupart des stations, tandis que les Diptères, les Oligochètes et les Hydracariens sont nettement abondants dans le cours inférieur mais de manière moins importante dans le cours moyen. Par ailleurs, une approche similaire de l'évolution longitudinale a été considérée afin d'évaluer la distribution entre les stations. Selon les niveaux trophiques, la classification entre les différentes communautés a été investiguée en se basant sur les liens trophiques existant entre elles en tenant compte des notions de "Groupe Fonctionnel Alimentaire " et du "River Continuum Concept ".

Mots-clés: zonation écologique, relations trophiques, macroinvertébrés, eau douce.

\section{INTRODUCTION}

The macrofauna plays a key role in the characterization and functioning of the aquatic ecosystems. It represents a good indicator of the health of the environment and a prime tool for the assessment of its quality. The macrofauna organisms have various interesting characteristics; they have a wide geographical distribution and a high biological diversity; they have also an integrating value to the variations of the environmental conditions and sensitivity to the environmental disturbances.

The Mediterranean and temperate climate confer specific environmental conditions to Algeria. The Mediterranean climate is characterized by a warm and dry summer and a wet winter, while in temperate regions, the summer is milder and the winter season is colder and wetter (Aschmann, 1973; Bonada et al., 2007). Climate change can likely have stronger implications for the local conservation of taxa than on the trait composition of the stream macroinvertebrate communities 
(Bonada et al., 2007). Numerous classifications of rivers and streams based on associations of aquatic species are reported in the literature (Huet, 1949; Illies \& Botosaneanu, 1963; Tate \& Heiny, 1995). The major advantage of such classifications is that the spatiotemporal stability of these associations can be used to define reference sites for rivers biological monitoring (Hughes et al., 1986). Indeed, any change in the composition and structure of the specific assemblages could be the consequence of environmental changes in a river belonging to a longitudinal section or to a region characterized by a populating type (Ward \& Stanford, 1983).

The specific diversity of the aquatic invertebrate communities depends on the habitat diversity and stability (Cummins, 1979; Ward \& Stanford, 1983), which define the heterogeneity of the ecological niches and thus of the possibilities for their development (Malmqvist \& Otto, 1987). The stream invertebrates are considered as primary and secondary consumers. A finer classification based on their feeding ecology was proposed by various authors (Cummins, 1973; Cummins \& Klug, 1979; Cummins \& Meritt, 1996), and the functional feeding groups were described according to the feeding mechanisms, the nature and the size of the introduced food particles as well as the adaptation for food acquisition. Hence, four functional feeding groups were defined by Cummins and Klug (1979):

- Shredders: usually prefer the organic particles higher than $1 \mathrm{~mm}$ called Coarse Particulate Organic Matter (CPOM) made up of vegetable remains colonized by microorganisms. Those are then transformed to Fine Particulate Organic Matter (FPOM).

- Collectors: use as food resource the Ultra-Fine Particulate Organic Matter (UPOM). They are subdivided into two categories; Filtering Collectors that capture and ingest nutriments in suspension and Gathering Collectors that can ingest the particle size range of the sediment (FPOM and UPOM).

- Scrapers: macroinvertebrates with morpho-behavioural adaptations for grazing upon food that adheres to surfaces periphyton in particular algae and associated microflora and for maintaining their position on exposed surfaces in rapid flowing waters.

- Predators: including all macro-invertebrates adapted for the capture of live preys, fragments of live preys or dead animals with a size higher than $1 \mathrm{~mm}$. They also have specific behavioural adaptations for capturing prey.

Despite the lack of related studies and records, the diversity of aquatic invertebrates is very high in the Algerian inland waters and it is often difficult to achieve the specific identification (Lounaci, 2005). This present survey is a crucial 
basis for future works, aiming at the development of taxonomic and functional indices of freshwater biological quality, taking into account the spatial variations of the benthic macro-invertebrates biodiversity. The aim of this investigation is to evaluate the longitudinal distribution of aquatic invertebrates sampled in the streams of the central north of Algeria in order to define the longitudinal sections based on the specific associations within the hydrographic network of Oued El Harrach basin.

\section{MATERIALS AND METHODS}

\section{Characteristics of the studied area}

Located south of Algiers, the considered streams of this investigation are Oued El Harrach and its main tributaries; Akhra, Boumaane and Maktaa Lazreg streams located in the central part of the Blida's Atlas. Considering the flow and length, Oued El Harrach is one of the longest in the Mitidja plain, with an area of $1270 \mathrm{~km}^{2}$.

The basin of Oued El Harrach is located in the north-central region of Algeria. It occupies a central position in the Tellian Atlas and extends from north to south over $53 \mathrm{~km}$ and from east to west over $31 \mathrm{~km}$. Oued El Harrach is $67 \mathrm{~km}$ away from the Mediterranean Sea.

The basin of Oued El Harrach is homogenious, mainly in its lower parts but with small hills in the downstream area. The hydrological network of the basin shows unequal areas; around one third of the falling occurs into the stream in the east-south and two-thirds of the falling is located at the confluence of Boumaane and Akhra streams. The most permeable falling in the south-west zone is constituted by "Schist of Chiffa" with a thickness estimated at more than $1000 \mathrm{~m}$, representing approximately $10 \%$ of the whole basin of Oued El Harrach (Mutin, 1977).

The climate in the area is influenced by the marine conditions from the north and by the sub-desert conditions arriving from the south. The predominant winds are north and north-east. The characteristics of the main seasonal local climate are:

- Cold and humid winter with high inter-annual irregularities of rainfall, with an average annual rainfall around $580 \mathrm{~mm}$, with temperature almost never below $0{ }^{\circ} \mathrm{C}$.

- $\quad$ Hot and dry summer with a marked total drought extending from June to September, and with temperature rarely exceeding $40^{\circ} \mathrm{C}$. 
Concerning the human disturbances in these rural areas, the agricultural activity is poorly developed and the crops are practically absent in the mountainous regions. As a result, the agricultural pollution is absent in the upstream and midstream waters. However, $1 \mathrm{~km}$ upstream the village "HammamMelouane", the anthropic activity is characterized by urban and industrial discharges, water pumping, car washing, cleaning of vegetables, sand and gravel extraction, quarrying, etc.

\section{Sampling sites}

Six sampling sites were positioned in the basin: Oued L'Akhra (Site 1), Oued Boumaane (Site 2) and Oued Maktaa Lazreg (Site 3). Together, these three streams form Oued El Harrach where three other sites were situated: Site 4 at 500 $\mathrm{m}$ from the confluence of the two last previously cited streams, Site 5 nearly at 1 $\mathrm{km}$ upstream the village "Hammam-Melouane" and Site 6 at $500 \mathrm{~m}$ downstream the village "Hammam-Melouane". These six sampling sites (Fig. 1) are located between an altitude of $143 \mathrm{~m}$ and $220 \mathrm{~m}$. The distribution of these sites within the hydrographic network was intended to capture the diversity of the habitats as well as the variability of the environmental characteristics likely to affect the geographical distribution of the aquatic macro-invertebrates (Table 1).

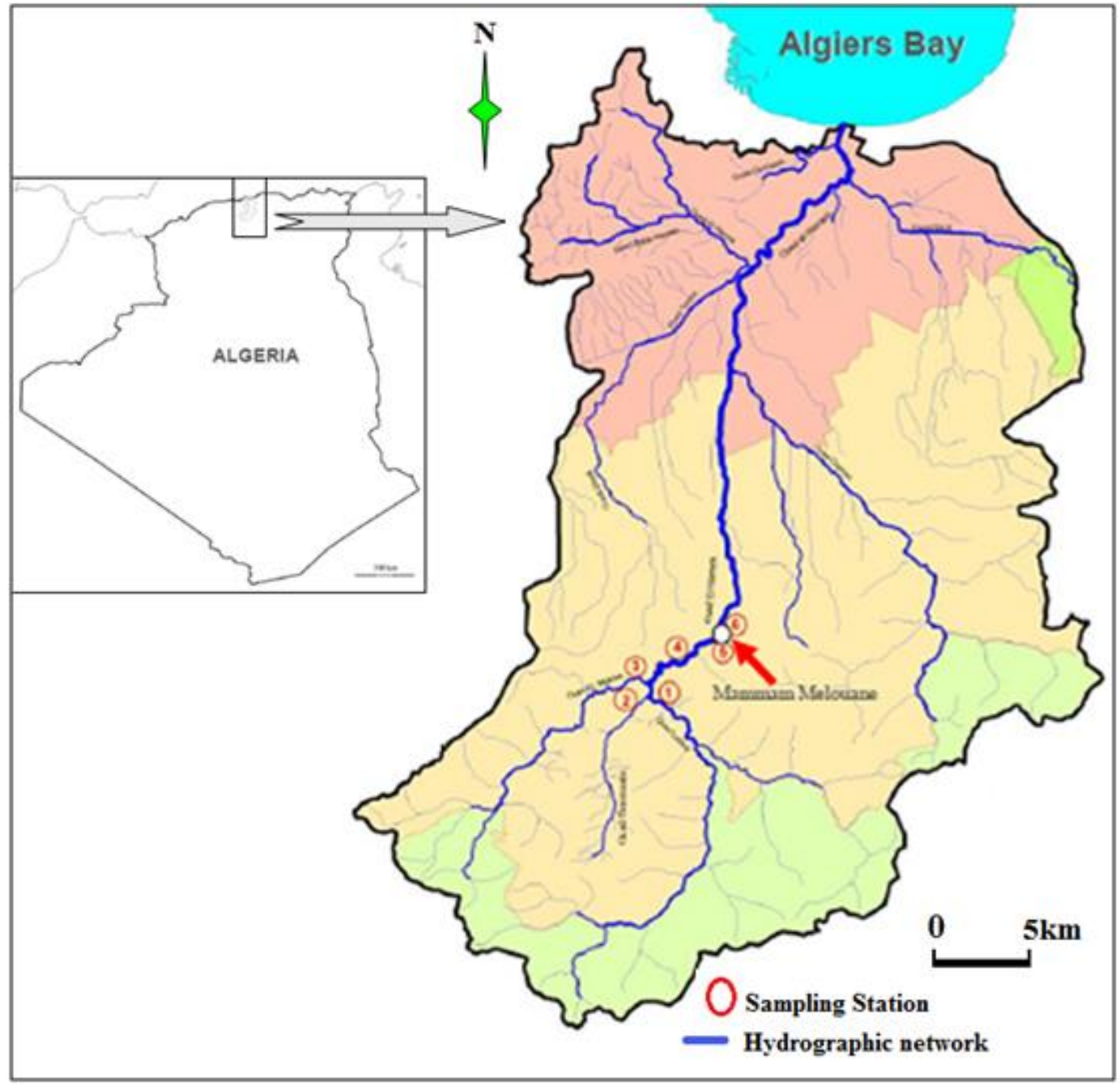


Figure 1. Location of the sampling sites in the hydrographic network of Oued El Harrach basin.

Table 1. Characteristics of the sampling sites.

\begin{tabular}{|c|c|c|c|c|c|c|}
\hline Site & $\mathbf{1}$ & 2 & 3 & 4 & 5 & 6 \\
\hline Location & O. L'Akhra & O. Boumaane & O. Maktaa & $\begin{array}{l}\text { O. El Harrach } \\
\text { upstream }\end{array}$ & $\begin{array}{c}\text { O. El } \\
\text { Harrach } \\
\text { upstream } \\
\text { Hammam } \\
\text { Melouane }\end{array}$ & $\begin{array}{c}\text { O. El Harrach } \\
\text { downstream } \\
\text { Hammam } \\
\text { Melouane }\end{array}$ \\
\hline Altitude (m) & 220 & 220 & 205 & 195 & 168 & 143 \\
\hline $\begin{array}{l}\text { Width of the bed } \\
\text { (m) }\end{array}$ & $5-10$ & 5 & $5-15$ & $5-15$ & $5-10$ & $5-10$ \\
\hline Depth (m) & $<0,50-1$ & $<0,50$ & $<0,50$ & $<0,50$ & $<0,50$ & $<0,50$ \\
\hline Slope & Weak & Weak & Weak & Weak & Weak & Weak \\
\hline $\begin{array}{l}\text { Nature of the } \\
\text { substrate }\end{array}$ & $\begin{array}{c}\text { Stone, } \\
\text { background } \\
\text { gravel, } \\
\text { stones, } \\
\text { rocks }\end{array}$ & $\begin{array}{c}\text { Stone, } \\
\text { background, } \\
\text { Gravel, } \\
\text { stones }\end{array}$ & $\begin{array}{l}\text { Gravel, } \\
\text { stones }\end{array}$ & $\begin{array}{c}\text { Sand, gravel, } \\
\text { stones }\end{array}$ & $\begin{array}{c}\text { Gravel, } \\
\text { stones }\end{array}$ & $\begin{array}{c}\text { Gravel, } \\
\text { stones, rocks }\end{array}$ \\
\hline Hydrophytes & $\begin{array}{l}\text { Filamentous } \\
\text { algae in } \\
\text { summer, } \\
\text { plant debris, } \\
\text { Phragmites } \\
\text { communis, } \\
\text { Nerium } \\
\text { oleander }\end{array}$ & $\begin{array}{l}\text { Filamentous } \\
\text { algae in } \\
\text { summer, } \\
\text { plant debris, } \\
P . \text { communis, } \\
\text { N. oleander }\end{array}$ & None & $\begin{array}{c}\text { Filamentous } \\
\text { algae in } \\
\text { summer }\end{array}$ & None & None \\
\hline Perilithon & Presence & Presence & None & None & None & None \\
\hline Fish refuges & $\begin{array}{l}\text { Stones, } \\
\text { rocks and } \\
\text { accessory } \\
\text { roots }\end{array}$ & Stones, rocks & $\begin{array}{l}\text { Stones, } \\
\text { rocks }\end{array}$ & $\begin{array}{c}\text { Stones, rocks, } \\
\text { underground } \\
\text { excavations }\end{array}$ & $\begin{array}{l}\text { Stones, } \\
\text { rocks }\end{array}$ & $\begin{array}{c}\text { Rocks, } \\
\text { underground } \\
\text { excavations }\end{array}$ \\
\hline Observations & $\begin{array}{c}\text { Swimming, } \\
\text { water } \\
\text { pumping }\end{array}$ & Swimming & $\begin{array}{l}\text { Swimming, } \\
\text { cleaning of } \\
\text { vegetables, } \\
\text { extraction of } \\
\text { sand }\end{array}$ & $\begin{array}{c}\text { Car washing, } \\
\text { civil } \\
\text { engineering } \\
\text { activities }\end{array}$ & Car washing & $\begin{array}{l}\text { Car washing, } \\
\text { cleaning of } \\
\text { vegetables, } \\
\text { crushing }\end{array}$ \\
\hline
\end{tabular}


From September 2012 to March 2014, samples were made in the dominant habitat for macro-invertebrates such as the rocky-bottom parts in the fast flowing streams (riffles) using a Surber's net with a metal frame (square foot sampler = $0.25 \mathrm{~m}^{2}$ ). The collected rocks within the frame were placed into a bucket of water then scrubbed to dislodge the invertebrates. The benthic macro-invertebrates were sampled in the six sites at 10 to $20 \mathrm{~cm}$ of water depth. A total of 63 samples were collected including rocks and gravel substrates from the lotic and lentic waters. Each sample was fixed in $10 \%$ Formaldehyde prior to laboratory observation with a stereomicroscope under low magnifications (10x to 30x) of both filtered and filtrate materials. Identification of the collected specimens was made on the basis of various keys of identification of aquatic invertebrates (Tachet et al. 1987, 2002; Richoux, 1982; Belfiore, 1983; Dakki \& El Agbani, 1983; Faessel, 1985).

\section{RESULTS AND DISCUSSION}

\section{Global Analysis of the Macroinvertebrates Communities}

Regarding the lack of taxonomic works and records on the aquatic fauna of Algeria (Lounaci et al., 2000a, 2000b; Lounaci \& Vinçon, 2005; Lounaci, 2005; Chaoui-Boudghene-Bendiouis et al., 2014; Chaoui-Boudghene-Bendiouis, 2016), during this investigation, the identification of the collected samples was often made at the order and family levels. In many cases, the generic and specific identifications were not made because of insufficient morphological details of specific identification in the consulted keys. However, the levels of identification of the present study allowed the assessment of the composition of the populations of the benthic fauna as well as the spatiotemporal distribution of macroinvertebrates.

Within the total collection (7451 individuals), the insects represent the major part of the harvested samples $(96.38 \%)$ with 44 taxa including 7 orders. Ephemeroptera dominated with 12 taxa (3677 individuals, 50.64\% of Total insects), followed by Diptera (11 taxa, 1233 individuals, $30.23 \%$ of total insects), and Trichoptera (6 taxa, 1233 individuals, $16.11 \%$ of total insects).

The orders Coleoptera, Hemiptera, Plecoptera and Odonata were weakly represented and the majority of these insects were collected at their larval stage, sometimes at the stage of nymph (Dipterous) or imago (Hemiptera and Coleoptera). The faunistic inventory comprises 58 taxa including 37 families, 2 subfamilies, 35 genus and 11 species. It is important to note that in the Mediterranean hydrosystems, the evolution richness is due to the seasonal effects (Khalaf \& Lahoud, 1983; Giudicelli et al. 1985; Doledec \& Chessel, 1989). 


\section{The Preliminary Ecological Classification}

According to their relative abundance, the preliminary analysis (Table 2) allowed distinguishing the upstream fauna (Plecoptera, Hemiptera, and Coleoptera), the ubiquitous fauna (Ephemeroptera, Trichoptera and Odonata) and the downstream fauna composed by Hydracarina, Oligochaeta and Chironomidae (Diptera) which is a pollution-resistant group.

Table 2. Distribution of the benthic fauna according to their relative abundance.

\begin{tabular}{|c|c|c|c|c|c|c|}
\hline Site & 1 & 2 & 3 & 4 & 5 & 6 \\
\hline Plecoptera & * & $* *$ & $\begin{array}{c}* * * \\
*\end{array}$ & & & \\
\hline Coleoptera & $*$ & $* * *$ & $* * *$ & $*$ & $*$ & $*$ \\
\hline Hemiptera & $* *$ & $* * *$ & * & $*$ & * & $*$ \\
\hline Ephemeroptera & $* *$ & $* *$ & $* * *$ & $* *$ & $*$ & $* *$ \\
\hline Trichoptera & $* *$ & $* *$ & $* * *$ & $*$ & $* *$ & $*$ \\
\hline Odonota & & $* * *$ & $* *$ & $*$ & $* *$ & $*$ \\
\hline Diptera & $*$ & $*$ & $*$ & $* *$ & $* *$ & $* * *$ \\
\hline Hydracarina & $*$ & $*$ & $*$ & $*$ & $* *$ & $* * *$ \\
\hline Oligocheta & $*$ & $*$ & $*$ & & $* * *$ & $* * *$ \\
\hline
\end{tabular}

$\mathbf{A}<10 \% *$

$25 \%>\mathbf{A} \geq 10 \% * *$ $75 \%>\mathbf{A} \geq 25 \% * * *$

$\mathbf{A} \geq 75 \% * * * *$

\section{Taxonomic classification}

According to the relationship between the relative abundance (A) and the frequency of the taxa (F) (Giudicelli, 1968), the taxonomic classification (Table 3) from the 63 samples allowed characterizing the hierarchy of the taxa into the following:

- Fundamental Taxa: About $12.5 \%$ of the Total taxa represented by the families Baetidae, Caenidae (Ephemeroptera), Chironomidae (Diptera) and Hydropsychidae (Trichoptera).

- Accessory Taxa: This category is strongly represented (64\%) by members of Ephemeroptera (except for Ephemera sp. and Oligoneuriella sp.). The main taxa belong to Diptera, Coleoptera, Hemiptera, Odonata, Trichoptera (Hydroptilidae), Oligochaeta except for Hydracarina and members of Tubificidae. 
- Sporadic Taxa: This category $(25 \%)$ is twice more important than the Fundamental taxa but is corresponding to the taxa with the weakest frequency such as Perla sp. and Isoperla sp. (Plecoptera), Gammarus sp. (Gammaridae; Amphipoda) and specimens of Tubificidae (Diptera).

\section{Feeding groups classification (Fig. 3 and Table 4)}

Collectors: Considering the averages from the whole collected fauna, the collectors are dominant $(85 \%)$ and are particularly more abundant in the downstream sampling stations. Indeed, Oued Maktaa stream receives allochthonous organic discharges (mainly vegetation detritus) from the neighbouring mountains.

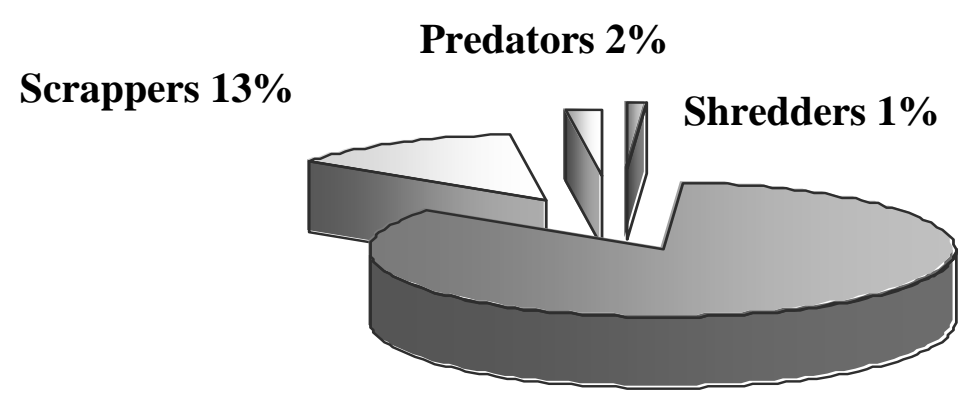

Figure 3. Percentage of feeding groups in all sampling sites.

Gathering Collectors (90\%): Mainly composed by Baetidae, Caenidae, Chironomidae and Ceratopogonidae. The gatherers corresponded to almost equal proportions of Diptera and Ephemeroptera.

Filtering Collectors (10\%): In the downstream of the village Maktaa Lazreg, the filterers are less present and are represented by Hydropsyche sp., Cheumatopsyche sp., Diplectrona sp. (Hydropsychidae) and members of Simulidae and Culicidae.

Scrapers: The samples are mainly composed by members of Heptageniidae, Elmidae, Corixidae and Tabanidae. Specimens of Oligochaeta (except for Naïdidae) are consumers of substrates and are classified separately by Doledec (1986) but attached to the Gathering collectors by Hawkins \& Sedell (1981) and Dudgeon (1984). The distribution of the scrapers is more equilibrated between different sampling sites. 
Predators: In this feeding group are included members of Odonata and Planarians (Tubellaria, Planariidae) as indicated by Doledec (1986). They were only found in the three last downstream sites and mostly represented weakly by specimens of Hydracarina.

Shredders: They are less represented by Gammarus $s p$. and by individuals of Tipulidae (Diptera). However, the abundance of the collectors ( $1 / 4$ filtering collectors, $3 / 4$ gathering collectors) lets us suggest that the presence of the shredders was predominant in the upstream side whereas in the downstream side the abundance of fine organic and ultrafine matters deposited on the substratum supports the development of specimens of Chironomidae and Ceratopogonidae that were found abundantly (63\%) in the latter side.

Table 3. Taxonomic classification according to Giudicelli (1968).

\begin{tabular}{|l|c|c|c|}
\hline Taxa & $\mathrm{F}$ & $\mathrm{A}$ & Classification \\
\hline Baetis & 9.65 & 29.826 & \\
Chironomidae & 80.95 & 18.716 & \\
Hydropsyche & 79.6 & 11.450 & Fundamental \\
Caenis & 6.49 & 7.567 & taxa \\
Heptagenia & 6.49 & 4.052 & \\
Ecdyonurus & 55.55 & 4.520 & \\
Cheumatopsyche & 2.980 & 5.280 & \\
\hline Ceratopogonidae & 41.26 & 6.051 & \\
Leptophlebia & 4.92 & 2.650 & \\
Limoniidae & 1.75 & 1.110 & \\
Hydracarina & 28.57 & 1.866 & \\
Siphlonurus & 19.04 & 0.705 & \\
Simulidae & 15.87 & 0.575 & \\
Oulimnius & 15.87 & 0.575 & \\
Habrophlebia & 14.28 & 0.666 & Accessory taxa \\
Micronecta & 12.69 & 0.614 & \\
Hydroptila & 12.69 & 0.562 & \\
Diplectrona & 11.11 & 0.578 & \\
Gomphus & 11.11 & 0.140 & \\
Rhithrogena & 9.52 & 0.900 & \\
Tabanidae & 9.52 & 0.248 & \\
Epeorus & 9.52 & 0.222 &
\end{tabular}




\begin{tabular}{|l|l|l|l|} 
Perlidae & 9.52 & 0.405 & \\
Gerris & 7.93 & 0.470 & \\
Lumbriculidae & 6.34 & 0.430 & \\
Ecnomus & 6.34 & 0.248 & \\
Laccobius & 3.17 & 0.156 & \\
Cordulegaster & 7.93 & 0.117 & \\
Esolus & 6.34 & 0.130 & \\
Elmis & 4.76 & 0.091 & \\
Other Elmidae & 4.76 & 0.065 & \\
Tipulidae & 4.76 & 0.065 & \\
Lumbricidae & 4.76 & 0.063 & \\
Stratiomyidae & 3.17 & 0.065 & \\
Oxyethira & 1.56 & 0.117 & \\
Aulonogyrus & 1.58 & 0.104 & \\
\hline Perla & 4.76 & 0.039 & \\
Ephemera & 3.17 & 0.039 & \\
Normandia & 3.17 & 0.039 & \\
Isoperla & 3.17 & 0.026 & \\
Tubificidae & 3.17 & 0.025 & \\
Oligoneuriella & 1.58 & 0.039 & Sporadic taxa \\
Gammarus & 1.58 & 0.025 & \\
Atherix & 1.58 & 0.012 & \\
Anthomyidae & 1.58 & 0.012 & \\
Dendrocoelumlacteum & 1.58 & 0.012 & \\
Planorbidae & 1.58 & 0.012 & \\
Agriotypus & 1.58 & 0.010 & \\
\hline & &
\end{tabular}

Table 4. Classification of functional trophic groups according to Cummins (1973) and Vannote et al. (1980).

\begin{tabular}{|c|c|c|c|c|c|c|c|c|}
\hline \begin{tabular}{|l} 
Feeding group \\
Site
\end{tabular} & 1 & 2 & 3 & 4 & 5 & 6 & & \\
\hline Tipulidae & & 1 & 2 & & 2 & & \multirow{2}{*}{\multicolumn{2}{|c|}{ Shredders }} \\
\hline Gammarus & & 2 & & & & & & \\
\hline Siphlonurus & 2 & & 34 & 40 & 2 & 3 & \multirow{5}{*}{ Filterers } & \multirow{5}{*}{$\begin{array}{c}\text { Collector } \\
\mathrm{s}\end{array}$} \\
\hline Hydropsyche & 111 & 197 & 269 & 74 & 123 & 100 & & \\
\hline Cheumatopsyche & 38 & 69 & 64 & 19 & 18 & 21 & & \\
\hline Diplectrona & 1 & 32 & 7 & 5 & 13 & & & \\
\hline Simulidae & 3 & 12 & 16 & & 24 & & & \\
\hline
\end{tabular}




\begin{tabular}{|c|c|c|c|c|c|c|c|}
\hline Culicidae & & & 44 & & & & \\
\hline Baetis & 128 & 351 & 599 & 574 & 267 & 371 & \multirow{10}{*}{ Gatherers } \\
\hline Other Baetidae & 7 & 2 & 7 & 11 & 1 & 2 & \\
\hline Caenis & 113 & 99 & 98 & 53 & 60 & 149 & \\
\hline Ephemera & 2 & & & & & 1 & \\
\hline Leptophlebia & 26 & 32 & 71 & 18 & 2 & 32 & \\
\hline Habrophlebia & 2 & 5 & 34 & 2 & & 8 & \\
\hline Gerris & 1 & 35 & & 3 & 9 & & \\
\hline Laccobius & & & & & 3 & 9 & \\
\hline $\begin{array}{l}\text { Chironomini+ } \\
\text { Tanytarsini }\end{array}$ & 51 & 23 & 98 & 292 & 210 & 754 & \\
\hline Ceratopogonidae & 31 & 21 & 36 & 130 & 26 & 218 & \\
\hline Ecdyonurus & 39 & 73 & 102 & 71 & 4 & 27 & \multirow{16}{*}{ Scrapers } \\
\hline Heptagenia & 51 & 99 & 96 & 42 & 14 & 10 & \\
\hline Epeorus & 1 & 11 & 1 & & 4 & & \\
\hline Rhithrogena & & 2 & 21 & 3 & & & \\
\hline Hydroptila & 13 & 6 & 10 & & 14 & & \\
\hline Oxyethira & & & 9 & & & & \\
\hline Esolus & & 9 & & & & & \\
\hline Normandia & & 3 & 1 & & & & \\
\hline Oulimnius & 2 & 15 & 21 & 3 & 2 & & \\
\hline Elmis & 2 & 4 & 1 & & & & \\
\hline Other Elmidae & & 1 & 2 & 2 & & & \\
\hline Micronecta & 15 & 15 & 8 & 4 & & 5 & \\
\hline Tabanidae & & 2 & 10 & & 3 & 4 & \\
\hline Lumbricidae & 2 & 1 & 2 & & & & \\
\hline Lumbriculidae & & 1 & 8 & & 22 & 3 & \\
\hline Tubificidae & 1 & & & 17 & 67 & & \\
\hline Ecnomus & 1 & 5 & 12 & 1 & & & \multirow{6}{*}{ Predators } \\
\hline Gomphus & & 1 & 4 & 1 & 4 & 1 & \\
\hline Cordulegaster & & 7 & & 1 & 1 & & \\
\hline Aulonogyrus & & 8 & & & & & \\
\hline Dendrocoelum lacteum & & 1 & & & & & \\
\hline Hydracarina & & & 9 & 28 & 42 & 54 & \\
\hline
\end{tabular}


In a first step, the analysed abundance and the established classifications permitted to distinguish the invertebrate faunal structure in the studied streams based on a longitudinal ecological zonation as indicated by Illies \& Botosaneanu (1963). In the Mediterranean hydrosystems, the evolution richness is influenced by the seasonal effects (Khalaf \& Lahoud, 1983; Khalaf, 1984; Giudicelli et al. 1985; Doledec \& Chessel, 1989) and this suggests that the chronological succession is associated with the specific biological rhythm of a considered taxa.

It is known that the hydrological regime contributes in a large part to the distribution of the faunistic structure and therefore to the area's typology. Gaschignard (1984) and Badri et al. (1987) indicated that the density and the taxonomic richness are strongly affected by the strong river flows, provided that such events do not provoke catastrophic effects on the ecosystem. However, the invertebrate fauna has the ability of an immediate reconstitution (Berrahou et al., 2001) and this particular pattern was observed during this survey following the strong flows in the studied streams during the rainy periods. On the other hand, the dryness can also provoke analogical effects such as during the high water levels (Boumezough et al., 1993).

Another longitudinal evolution approach based on the two concepts of "Feeding Functional Group" (Cummins, 1973) and the "River Continuum" (Vannote et al., 1980) was adopted in order to link this evolution to inter-site differences. The shredders, although weakly represented, were found in Oued Maktaa Lazreg where plant debris are abundant. In the upstream of Oued El Harrach (Site 4), the abundance of fine and ultrafine organic matters favours the dominance of the gathering-collectors such as Baetis sp. and Caenis sp. (Ephemeroptera). In the downstream area of Oued El Harrach (Site 6), Chironomidae and Ceratopogonidae (Diptera) were found abundantly. Globally, the collected macro-invertebrates communities are dominated by collectors.

\section{ACKNOWLEDGEMENT}

The authors are grateful to the anonymous reviewers' constructive and useful comments on the manuscript.

\section{REFERENCES}

Aschmann, H. 1973. Distribution and peculiarity of Mediterranean ecosystems. Pp. 11-19 In: Mediterranean Type Ecosystems: Origin and Structure (F. Di Castria and H.A. Mooney Editors), Springer-Verlag, New York. 
Badri, A., Giudicelli, J. et Prevot, G. 1987. Effets d'une crue sur la communauté d'invertébrés benthiques d'une rivière méditerranéenne, Le Rdat (Maroc). Acta Ecologica/Ecol. Gener., 8(4): 481-500.

Belfiore C. 1983. Efemerettori. Guide per il riconoscimento delle specieanimali delle aque interne italiane. Consiglio Nazionale delle Ricerche, Veronica., 24: 112.

Berrahou, A., Cellot, B., Richoux P. 2001. Distribution longitudinale des macroinvertébrés benthiques de la Moulouya et de ses principaux affluents (Maroc). Annales de Limnologie, 37, 223-235.

Bonada N., Doledec S. and Statzner B. 2007.Taxonomic and biological trait differences of stream macroinvertebrate communities between Mediterranean and temperate regions: implications for future climatic scenarios. Global Change Biology, 13: 1658-1671.

DOI: 10.1111/j.1365-2486.2007.01375.x

Boumezough, A., Alifriqui, B., Musso, J. J. et Prevot. G. 1993. Impact de crues sur les peuplements de macroinvertébrés aquatiques et rivulaires d'un cours d'eau du Haut-Atlas Central: Ourika (Maroc). Comm. $2^{\text {ème }}$ Congrès Intern. Limnologie-Océanographie. Evian.

Chaoui-Boudghene-Bendiouis, C., Abdellaoui-Hassaïne, K., Belqat, B., Franquet, E., Boukli Hacène, S. and Yadi, B. 2014. Habitat characterization of Black flies (Diptera: Simulidae) in the catchment of Western Algeria. Open Journal of Ecology, 4:1014-1024.

Chaoui-Boudghene-Bendiouis, C. 2016. Caractérisation et modélisation des habitats des Simulies (Diptera: Simulidae) du bassin versant de la Tafna. Thèse doct. Univ. Tlemcen, $71 \mathrm{pp}$.

Cummins, K. W. 1973. Trophic relations of aquatic insects. Ann. Rev. Entomol., 18: 183-206.

Cummins, K. W., Klug J. M. 1979. Feeding ecology of stream invertebrates. Ann. Rev. Ecol. Syst., 10: 147-172.

Cummins, K. W. and Meritt, R.W. 1996. Ecology and Distribution of Aquatic Insects. Pages 74-86 in An Introduction of Aquatic Insects of North America. R.W. Meritt and Cummins K. W. eds. $3^{\text {rd }}$ edition. Kendall/Hunt Publishing Company, Dubuque, Iowa.

Dakki, M. et El Agbani, M.A. 1983. Ephéméroptères d'Afrique du Nord. 3. Éléments pour la connaissance de la faune marocaine. Bull. Inst. Sci. Rabat, 7: 115-126.

Doledec, S. 1986. Les peuplements de macroinvertébrés benthiques du cours inférieur de l'Ardèche. Dynamique spatio-temporelle. Thèse Doct. Univ. Claude Bernard Lyon I. 246 pp.

Doledec, S. et Chessel, D. 1989. Rythmes saisonniers et composantes stationnelles en milieu aquatique. II. Prise en compte et élimination 
d'effets dans un tableau faunistique. Acta Ecologica / Ecol. Gener. 10 (3): 207-232.

Dudgeon, D. 1984. Longitudinal and temporal changes in functional organization of macoinvertebrates communities in the Lam Tsuen River, Hong Kong. Hydrobiology, 111:207-217.

Faessel, B. 1985. Les Trichoptères. Données biologiques, éthologiques et écologiques. Clé de détermination larvaire des familles et des principaux genres de France. Bull. Fr. Pêche Piscic., 299:1-14.

Gaschignard, O. 1984. Impact d'une crue sur les macroinvertébrés benthiques d'un bras du Rhône. Verh. Internat. Verein Limnol., 22:1997-2001.

Giudicelli, J. 1968. Recherches sur le peuplement, l'écologie, la biogéographie d'un réseau hydrographique de la Corse centrale. Thèse Doct. ès Sciences, Univ. Aix, Marseille: 437 pp.

Giudicelli, J., Dakki, M., Dia, A. 1985. Caractéristiques abiotiques et hydrologiques des eaux courantes méditerranéennes. Verh. Internat. Verein. Limnol., 22:2094-2101.

Hawkins, C.P. and Sedell, J.R. 1981. Longitudinal and seasonal changes in functional organization of macroinvertebrates communities in four Oregon streams. Ecology, 62, 2:387-397.

Huet, M., 1949. Appréciation de la valeur piscicole des eaux douces. Trav. Stat. Rech. Eaux et Forêts, Groenendaal., Série D 10, 55 pp.

Hughes, R. M., D.P Larsen, and J. M. Omernik. 1986. Regional reference sites: a method for assessing stream pollution. Environ. Manage., 10 (05):629-35.

Illies, J. et Botosaneanu, L. 1963. Problèmes et méthodes de la classification et de la zonation écologique des eaux courantes. Mitt. Int. Verein. Limnol., 12: $1-57$.

Khalaf, G. et Lahoud, M. 1983. Contribution à l'étude écologique des fleuves côtiers du Liban. I. Le Nahr-el-Kalb. Bull. Soc. Linn.Lyon, 1: 21-32.

Khalaf, G. 1984. Contribution à l'étude écologique des fleuves côtiers du Liban. II. Cours moyen et inférieur du Nahr Ibrahim. Bull. Soc. Linn. Lyon, 1: 920.

Lounaci, A., Brosse S., Ait Mouloud S., Lounaci-Daoudi D. and Mebarki M. 2000a. Current knowledge of benthic invertebrate diversity in an Algerian stream: a species check-list of the Sebaou River basin (Tizi-Ouzou). Bull. Soc. Hist. Nat., Toulouse, 136: 43-55.

Lounaci, A., Brosse S., Thomas, A.G.B. and Lek, S. 2000b. Abundance, diversity and community structure of macroinvertebrates in an Algerian stream: the Sebaou wadi. Annls Limnol., 36(2): 123-133

Lounaci, A. et Vinçon, G. 2005 - Les Plécoptères de la Kabylie du Djurdjura (Algérie) et Biogéographie des espèces d'Afrique du Nord [Plecoptera]. Ephemera, 6(2): 109-124. 
Lounaci, A. 2005. Recherche sur la faunistique, l'écologie et la biogéographie des macroinvertébrés des cours d'eau de Kabylie (Tizi-Ouzou, Algérie). Thèse de doctorat d'état. Univ. Mouloud Mammeri, Tizi-Ouzou (Algérie). $208 \mathrm{pp}$.

Malmqvist, B. and Otto, C. 1987. The influence of substrate stability on the composition of stream benthos: an experimental study. Oikos, 48: 33-38.

Mutin, G. 1977. La Mitidja, décolonisation et espace géographique. O.P.U. Alger.

Richoux, P. 1982. Introduction pratique à la systématique des organismes des eaux continentales françaises. 2. Coléoptères aquatiques. Bull. Soc. Linn. Lyon., 4: 105-303.

Tachet, H., Bournaud, M., Richoux, P. 1987. Introduction à l'étude des macroinvertébrés des eaux douces. Assoc. Franç. Limnol. Lyon.

Tachet, H., Richoux, P., Bournaud, M., Usseglio-Polatera, P. 2002. Invertébrés d'Eau Douce ( $2^{\text {nd }}$ corrected impression). CNRS éditions, Paris.

Tate, C. M. and Heiny, J. S. 1995. The ordination of benthic invertebrate communities in the South Platte River Basin in relation to environmental factors. Freshwater Biology, 33: 439-454.

Vannote, R.L., Minshall, G.W., Cummins, K.W., Sedell, J.R., Cushing, C.E. 1980. The river continuum concept. Can. J. Fish. Aquat. Sci., 37: 130-137.

Ward, J. V. and Stanford, J. A. 1983. The serial discontinuity concept of lotic ecosystems. Pp. 29-42 In:T. D. Fontaine \& S. M. Bartell (Eds.), Dynamics of Lotic Ecosystems. Ann. Arbor. Science. 